\title{
SISTEM INFORMASI PENCATATAN MATERIAL UNTUK PENGADAAN BARANG MASUK DAN KELUAR
}

\author{
Maksum Tanubrata ${ }^{1}$ Andya Basanta ${ }^{2}$ \\ ${ }^{1}$ Dosen Tetap Jurusan Teknik Sipil, Fakultas Teknik, Universitas Kristen Maranatha \\ Jl. Prof. drg. Suria Sumantri, MPH., No. 65, Bandung, 40164 \\ Email : maksum.tanubrata150@gmail.com \\ ${ }^{2}$ Alumnus Jurusan Teknik Sipil Program Double Degree (dengan Sistem Informasi) \\ Fakultas Teknik Universitas Kristen Maranatha \\ Jl. Prof. drg. Suria Sumantri, MPH., No. 65, Bandung, 40164 \\ Email: andyabasanta@gmail.com
}

\begin{abstract}
ABSTRAK
Manajemen material pada proyek konstruksi sipil yang kurang baik seringkali mengakibatkan keterlambatan penyelesaian proyek. Dapat ditemukan beberapa masalah di lapangan seperti pembuatan dokumentasi data pembelian \& penggunaan material konstruksi dan laporan yang masih dilakukan secara manual, sulitnya di lapangan untuk mengecek ketersediaan material konstruksi dan dibutuhkannya proses autorisasi untuk mengeluarkan material konstruksi dari gudang. Untuk menyelesaikan masalah di atas, dibutuhkan bantuan dari bidang ilmu lain, dalam hal ini Sistem Informasi untuk membantu memanajemen material pada sebuah proyek konstruksi. Dengan adanya Sistem Informasi dapat ditemukan masalah pada sistem di lapangan yang dinilai dapat dirubah, kemudian dibuat sebuah sistem baru untuk menyelesaikan masalah tersebut. Dengan adanya aplikasi dengan bahasa pemrograman Java ini diharapkan dapat membantu pihak - pihak yang bekerja pada sebuah proyek konstruksi untuk memanajemen material di lapangan. Dengan menggunakan aplikasi ini manajemen material akan menjadi lebih mudah, cepat, aman, efisien, akan ada pengurangan dalam penggunaan kertas kerja dan pengurangan pekerjaan yang masih dilakukan secara manual.
\end{abstract}

Kata kunci : manajemen, material, informasi

\begin{abstract}
Lack of good materials management in civil construction project can cause delay to the project. There are some issues in the field such as : manually created documentation of purchased \& used construction materials and reports, how inconvenient it is to check the availability stock of construction materials, and the need of authorization to make some materials purchasing or carrying out construction materials from the warehouse. To solve these problems, helps from other disciple, in this case is System Information is needed to manage materials in a civil construction project. With System Information problems inside the system in the field which is considered must be changed can be found, and then make a new system that can solve these problems. With this Java language application, there is a hope that this application can helps people working on a civil construction project to manage materials in the field. Therefore with this application materials management will be easier, faster, more secure, more efficient, there will be reduced use of paperwork and lesser manual works done.
\end{abstract}

Keywords : management, material, information

\section{PENDAHULUAN}

\section{Latar Belakang}

Pada sebuah proyek konstruksi, pengadaan material konstruksi di lapangan merupakan sebuah pekerjaan yang memiliki peranan sangat penting. Pengadaan material 
konstruksi ditentukan oleh berbagai faktor seperti penjadwalan, jenis pekerjaan dan kebutuhan material.

Selain banyaknya faktor yang menentukan, banyaknya pihak yang terlibat dan bertanggung jawab dalam pengadaan material konstruksi serta prosedur - prosedur yang harus dilakukan membuat proses pengadaan material konstruksi menjadi sebuah pekerjaan yang rumit.

Melihat masalah ini, dibutuhkan sebuah aplikasi pencatatan material konstruksi, dimana aplikasi ini membantu pihak - pihak yang bekerja di lapangan untuk mencatat semua data material konstruksi serta data pengadaan material konstruksi baik itu material masuk maupun material keluar. Diharapkan juga dengan adanya aplikasi ini dapat mengurangi penggunaan kertas ( paperwork) dan mengurangi pekerjaan yang dilakukan secara manual sehingga proses pengadaan material menjadi lebih efisien.

\section{Tujuan}

Setelah melakukan survei di lapangan untuk mengetahui proses pengadaan material konstruksi secara langsung dan mengetahui kekurangan dan kebutuhan di lapangan dibuatlah sebuah aplikasi pencatatan yang bertujuan untuk :

1. Membuat proses pencatatan material konstruksi di lapangan menjadi terintregrasi sehingga lebih cepat dan efisien

2. Mengurangi penggunaan kertas ( paperwork) dan kebutuhan autorisasi( tanda tangan ) pada kertas dari pihak - pihak yang terlibat sehingga proses pengadaan material konstruksi menjadi lebih mudah.

3. Menghasilkan laporan pembelian dan / atau laporan penggunaan material harian dan / atau mingguan sesuai dengan kebutuhan

\section{Ruang Lingkup}

Batasan Masalah bidang Sipil:

1. Pengamatan ini dikhususkan pada pengadaan material konstruksi yang masuk dan keluar pada proyek konstruksi

2. Barchart atau penjadwalan proyek sudah tersedia sebelumnya untuk mengetahui material konstruksi yang dibutuhkan

3. Susunan organisasi dan prosedur pengadaan sudah ditentukan

Batasan masalah bidang Sistem Informasi: 
1. Sistem Operasi : Microsoft Windows 7

2. Sistem Basis Data : MySql

3. Bahasa Scripting : Java

4. Editor Pemrograman : NetBeans

Batasan Aplikasi:

1. Hak akses adalah user yang telah terdaftar pada aplikasi

2. User dibagi menjadi 4 ( empat ) buah yaitu Project Manager, Supervisor, Purchasing, serta Gudang.

3. Setiap User memiliki akses yang berbeda ke dalam fitur aplikasi ini sesuai dengan tanggung jawab dan kebutuhannya masing - masing

4. Aplikasi ini tidak mencatat penjadwalan

\section{TINJAUAN PUSTAKA}

\section{Manajemen Proyek}

Manajemen proyek dapat didefinisikan sebagai suatu proses dari perencanaan, pengaturan, kepemimpinan, dan pengendalian dari suatu proyek oleh para anggotanya dengan memanfaatkan sumber daya seoptimal mungkin untuk mencapai sasaran yang telah ditentukan. Fungsi dasar manajemen proyek terdiri dari pengelolaan-pengelolaan lingkup kerja, waktu, biaya, dan mutu. Pengelolaan aspek-aspek tersebut dengan benar merupakan kunci keberhasilan dalam penyelenggaraan suatu proyek.

Dengan adanya manajemen proyek maka akan terlihat batasan mengenai tugas, wewenang, dan tanggung jawab dari pihak-pihak yang terlibat dalam proyek baik langsung maupun tidak langsung, sehingga tidak akan terjadi adanya tugas dan tangung jawab yang dilakukan secara bersamaan (overlapping).

Apabila fungsi-fungsi manajemen proyek dapat direalisasikan dengan jelas dan terstruktur, maka tujuan akhir dari sebuah proyek akan mudah terwujud, yaitu:

1. Tepat Waktu

2. Tepat Kuantitas

3. Tepat Kualitas

4. Tepat Biaya sesuai dengan biaya rencana

5. Tidak adanya gejolak sosial dengan masyarakat sekitar

6. Tercapainya K3 dengan baik 
Pelaksanaan proyek memerlukan koordinasi dan kerjasama antar organisasi secara solid dan terstruktur. Dan hal inilah yang menjadi kunci pokok agar tujuan akhir proyek dapat selesai sesuai dengan schedule yang telah direncanakan

\section{Hierarki Organisasi Proyek dan Job Description Definisi Hierarki Organisasi Proyek}

Hierarki Organisasi Proyek atau Organazing Analysis Table (OAT) adalah susunan organisasi yang bertingkat mulai dari tingkat paling atas seperti pimpinan proyek sampai paling akhir misalnya pelaksana. Hierarki ini disusun dengan tujuan mempermudah pengelolaan dan alokasi SDM sesuai dengan tanggung jawab dalam organisasi proyek. Keberhasilan penyelenggaraan proyek biasanya ditunjang oleh organisasi dengan susunan dan program kerja, yang sasaran dan tujuannya tertata dengan baik.

Tanggung jawab personel dibagi berdasarkan tingkatan pada elemen pekerjaan. Tanggung jawab ini disesuaikan dengan kemampuannya dalam menangani beban tugas yang diberikan kepadanya. Personel mempunyai kemampuan dan keterampilan dengan tingkat pendidikan yang cukup, sehingga dapat bekerja untuk tugas - tugas mandiri atau bekerja dalam satu tim proyek untuk memecahkan masalah - masalah yang muncul selama berlangsungnya suatu proyek.

Personel yang bertanggung jawab pada pada masing - masing tingkatan ini, telah memahami tugas berdasarkan job description dan prosedur operasional pelaksanaan proyek, sehingga segala penyimpangan yang terjadi dapat dideteksi lebih awal dan memudahkan tindakan koreksi dengan melokalisasi personel tersebut serta memungkinkan manajemen malakukan pengendalian terhadap seluruh pekerjaan.

\section{Job Description}

Menurut Siswanto ( 2002:128 ) Job Description adalah catatan yang sistematis tentang tugas dan tanggung jawab suatu jabatan tertentu, yang ditulis berdasarkan faktafakta yang ada. Penyusunan catatan ini sangat penting, terutama untuk menghindarkan terjadinya perbedaan pengertian, untuk menghindari terjadinya pekerjaan rangkap serta untuk mengetahui batas-batas tanggung jawab dan wewenang masing-masing jabatan. 


\section{Hal-hal yang perlu dicantumkan dalam Uraian Jabatan pada umumnya meliputi :}

1. Identifikasi Jabatan, yang berisi informasi tentang nama jabatan, bagian dan nomor kode jabatan dalam suatu perusahaan

2. lkhtisar Jabatan, yang berisi penjelasan singkat tentang jabatan tersebut; yang juga memberikan suatu definisi singkat yang berguna sebagai tambahan atas informasi pada identifikasi jabatan, apabila nama jabatan tidak cukup jelas

3. Tugas-tugas yang harus dilaksanakan. Bagian ini adalah inti dari Uraian Jabatan dan merupakan bagian yang paling sulit untuk dituliskan secara tepat. Untuk itu, bisa dimulai menyusunnya dengan mencoba menjawab pertanyaan-pertanyaan tentang apa dan mengapa suatu pekerjaan dilaksanakan, dan bagaimana cara melaksanakannya

4. Pengawasan yang harus dilakukan dan yang diterima. Bagian ini menjelaskan namanama jabatan yang ada diatas dan di bawah jabatan ini, dan tingkat pengawasan yang terlibat

5. Hubungan dengan jabatan lain. Bagian ini menjelaskan hubungan vertikal dan horizontal jabatan ini dengan jabatan-jabatan lainnya dalam hubungannya dengan jalur promosi, aliran serta prosedur kerja

6. Mesin, peralatan dan bahan-bahan yang digunakan

7. Kondisi kerja, yang menjelaskan tentang kondisi fisik lingkungan kerja dari suatu jabatan. Misalnya panas, dingin, berdebu, ketal, bising dan lain-lain terutama kondisi kerja yang berbahaya

8. Komentar tambahan untuk melengkapi penjelasan di atas

\section{Sistem Informasi}

Sistem Informasi dapat dibedakan menjadi dua jenis, sistem informasi manual dan sistem informasi berbasis computer (CBIS). CBIS selanjutnya akan disebut sebagai sistem informasi saja. Ada beberapa pendapat mengenai pengertian sistem informasi itu sendiri, antara lain : 
Tabel 1. Pengertian Sistem Informasi.

\begin{tabular}{|c|c|c|}
\hline NO & PENCETUS & PENGERTIAN \\
\hline 1. & Gelinas, Oram, dan Wiggins (1990) & $\begin{array}{l}\text { Sistem informasi adalah suatu sistem } \\
\text { buatan manusia yang secara umum } \\
\text { terdiri atas sekumpulan komponen } \\
\text { berbasis komputer dan manual yang } \\
\text { dibuat untuk menghimpun, } \\
\text { menyimpan, dan mengelola data serta } \\
\text { menyediakan informasi keluaran } \\
\text { kepada para pemakai }\end{array}$ \\
\hline 2. & Alter (1992) & $\begin{array}{l}\text { Sistem informasi adalah kombinasi } \\
\text { antar prosedur kerja, informasi, orang, } \\
\text { dan teknologi informasi yang } \\
\text { diorganisasikan untuk mencapai tujuan } \\
\text { dalam sebuah organisasi }\end{array}$ \\
\hline 3. & Wilkinson (1992) & $\begin{array}{l}\text { Sistem informasi adalah kerangka kerja } \\
\text { yang mengkoordinasikan sumber daya } \\
\text { (manusia , komputer) untuk mengubah } \\
\text { masukan (input) menjadi keluaran } \\
\text { (informasi), guna mencapai sasaran } \\
\text { perusahaan }\end{array}$ \\
\hline 4. & Bodnar dan Hopwood (1993) & $\begin{array}{l}\text { Sistem informasi adalah kumpulan } \\
\text { perangkat lunak yang dirancang untuk } \\
\text { mentransformasikan data ke dalam } \\
\text { bentuk informasi yang berguna }\end{array}$ \\
\hline 5. & Turban, McLean, dan Wetherbe (1990) & $\begin{array}{l}\text { Sebuah sistem informasi } \\
\text { mengumpulkan, memproses, } \\
\text { menyimpan. Menganalisis, dan } \\
\text { menyebarkan informasi untuk tujuan } \\
\text { yang spesifik }\end{array}$ \\
\hline
\end{tabular}


Tabel 1. Lanjutan.

\begin{tabular}{|c|c|c|}
\hline 6. & Hall (2001) & $\begin{array}{l}\text { Sistem informasi adalah sebuah } \\
\text { rangkaian prosedur formal dimana data } \\
\text { dikelompokkan, diproses menjadi } \\
\text { sistem informasi, dan didistribusikan } \\
\text { kepada pemakai }\end{array}$ \\
\hline
\end{tabular}

Sistem Informasi mempunyai beberapa peranan, antara lain :

1. Berpatisipasi dalam pelaksanaan tugas - tugas (otomasi).

2. Mengaitkan perencanaan, pengerjaan, dan pengendali dalam subsistem.

3. Mengkoordinasikan dan mengintegrasikan subsistem-subsistem.

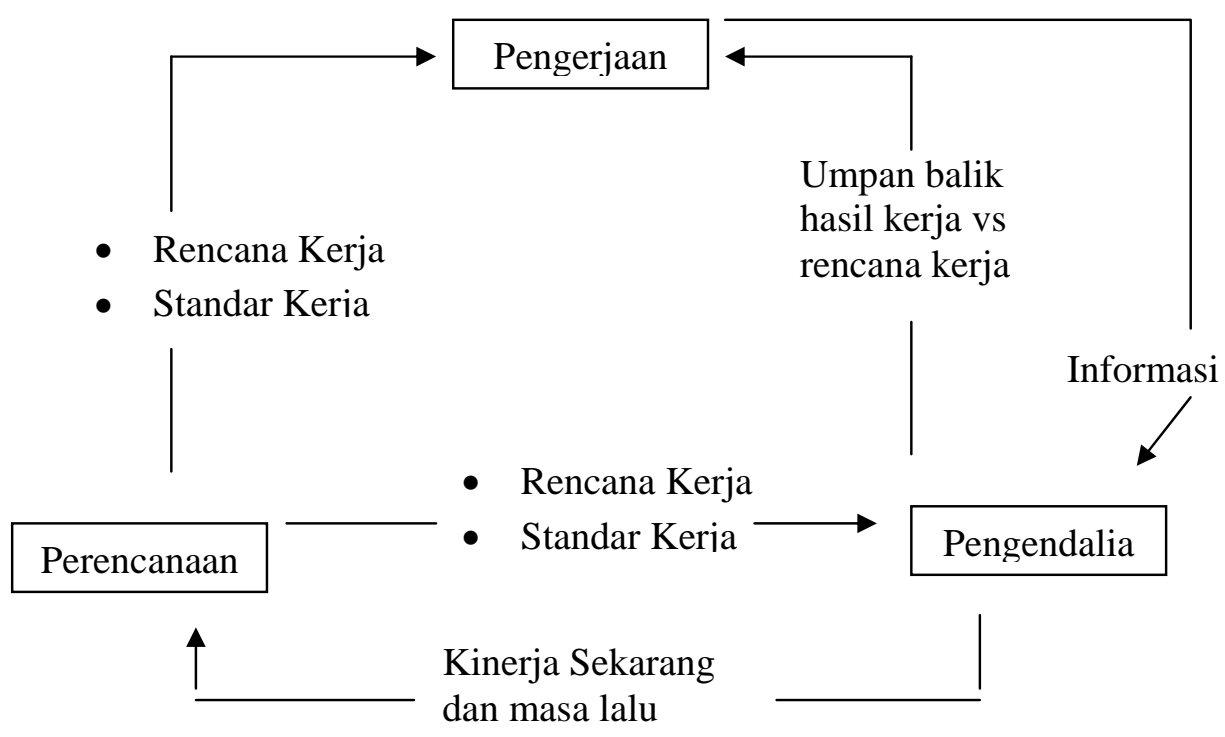

Gambar 1. Hubungan Pengerjaan, Perencanaan, dan Pengendalian.

\section{STUDI KASUS}

\section{Data Proyek}

Nama Perusahaan

Alamat Perusahaan

Nama Pimpinan

Nama Proyek

Alamat

Jenis Konstruksi

66
: PT. Dago Endah

: Jl. Lapangan Golf Atas

: Bapak Bambang Prihutomo

: Renovasi Lapangan Golf \& Club House

: Jl. Lapangan Golf Atas

: Beton 

Jenis Pondasi
: Batu Kali
Luas Tanah
: $1300 \mathrm{~m}^{2}$
Luas Bangunan
: $2600 \mathrm{~m}^{2}$
Jumlah Lantai
: 2 Lantai
Fungsi Proyek
: Club House
Kontraktor
: PT. Wirabina Semarang
Konsultan Pengawas
: PT. Ceria Jasa
Konsultan Arsitek
: Bapak Andra Martin
Nilai Proyek
: Rp. 12.000.000.000,00

\section{Susunan Organisasi Proyek}

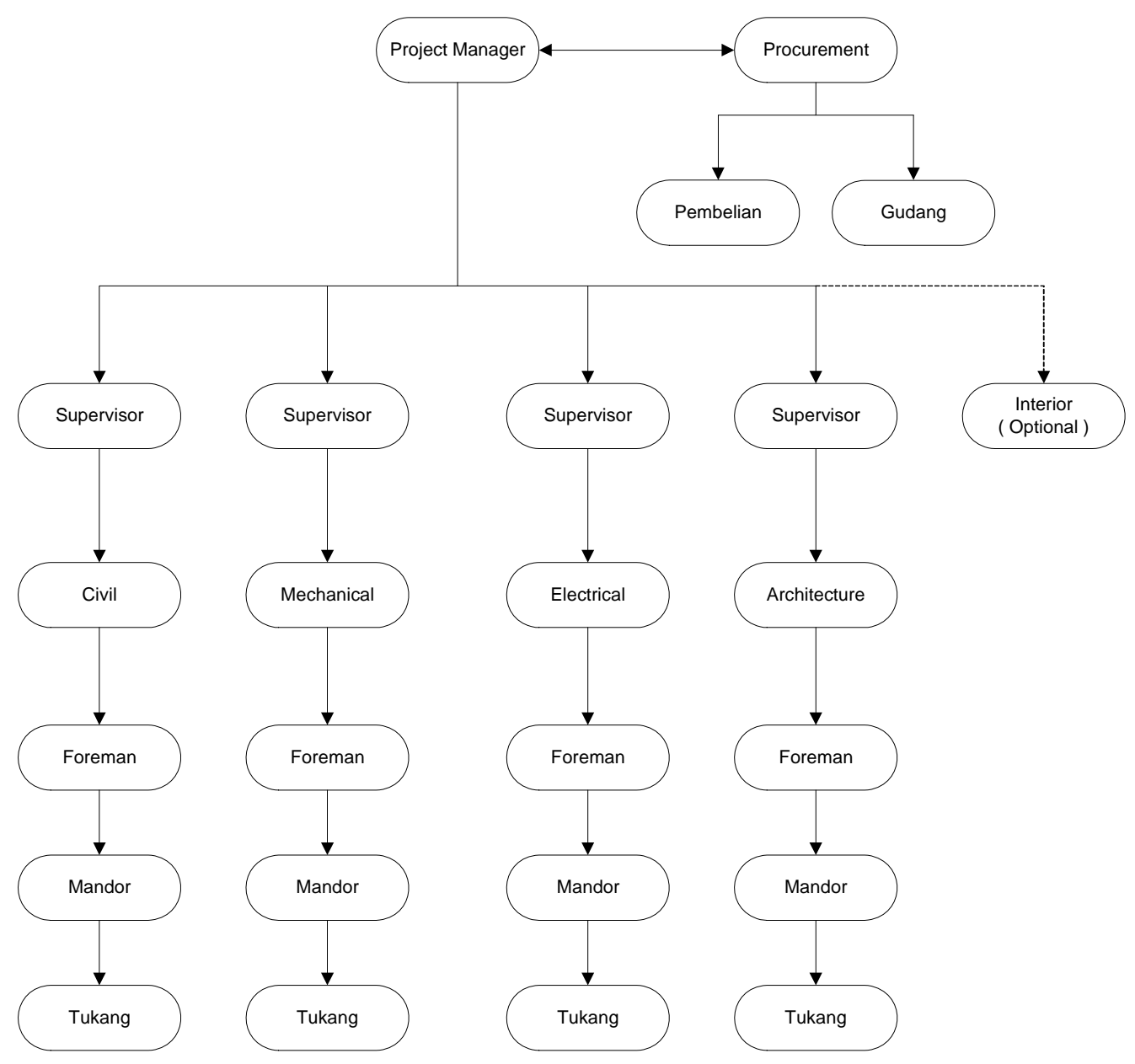

Gambar 2. Hierarki Organisasi Proyek Renovasi Lapangan Golf

\& Club House PT. Dago Endah.

Sistem Informasi Pencatatan Material untuk Pengadaan Barang Masuk dan Keluar (Maksum Tanubrata, Andya Basanta) 


\subsection{Proses Bisnis}

Dalam proses bisnisnya, pada pelaksanaan suatu proyek konstruksi memiliki kaitan yang sangat erat dengan material. Berhubungan dengan hal ini dibutuhkan sistem untuk memanajemen material secara keseluruhan, sehingga setiap material dapat terdata dengan jelas dari sejak pembelian sampai dengan penggunaannya.

Pertama semua material dicatat kedalam sebuah database, begitu juga dengan daftar supplier yang akan mensuplai material tersebut. Setelah data material dan supplier terisi kemudian dilakukan pembelian material, sesuai kebutuhan di lapangan. Jumlah material dan tanggal pembelian serta total pembelian akan tercatat.

Kemudian saat material telah diantar, dilakukan penerimaan dan stok pada lapangan akan bertambah, dan bila ada pengeluaran maka stok di lapangan juga akan berkurang. Setelah semua data tercatat dapat dilakukan pencetakan laporan, sesuai dengan berbagai kebutuhan yang diperlukan dilapangan.

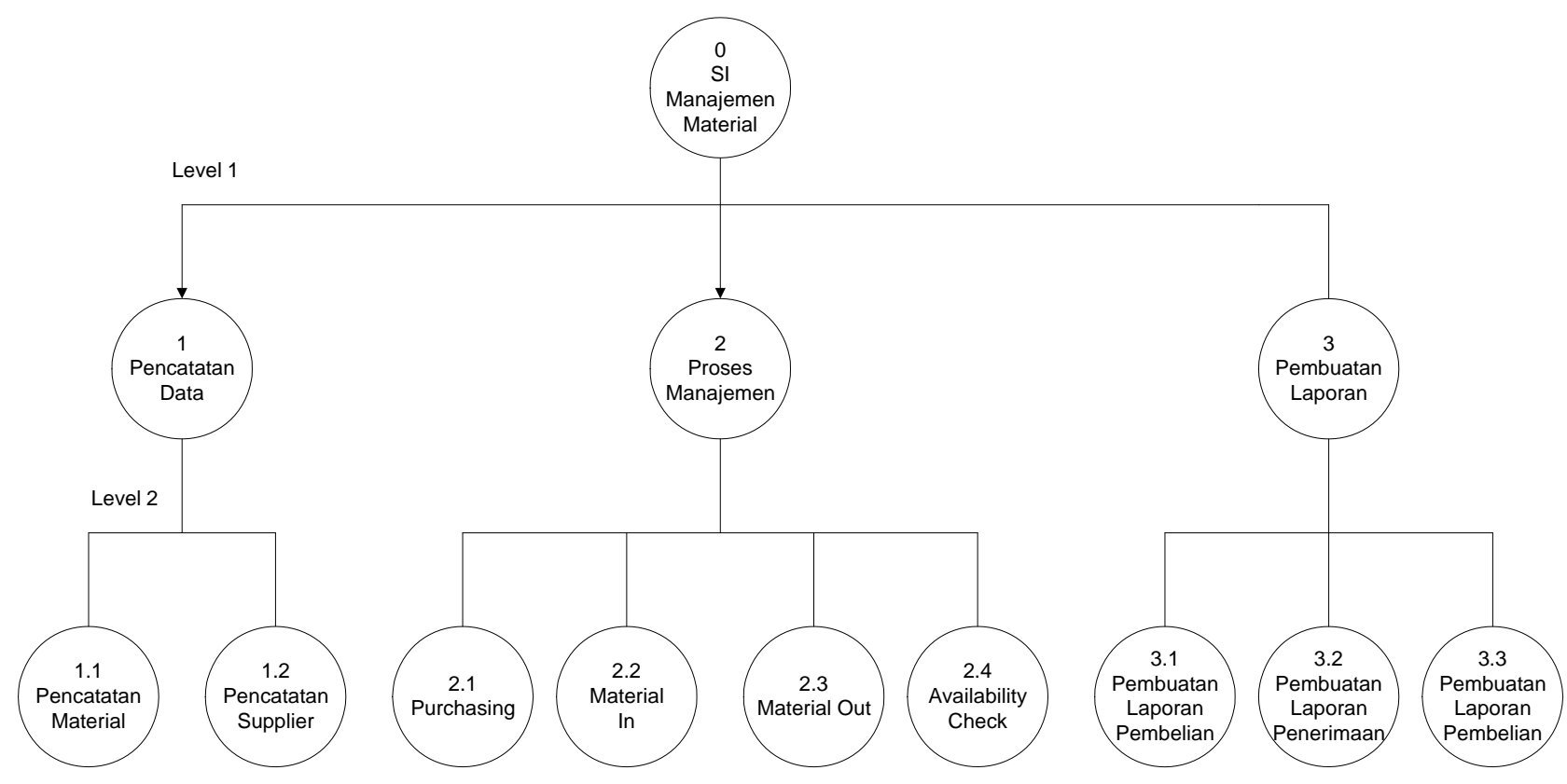

Gambar 3. Dekomposisi Sistem Informasi Manajemen Material. 


\section{Rancangan Diagram Entitas}

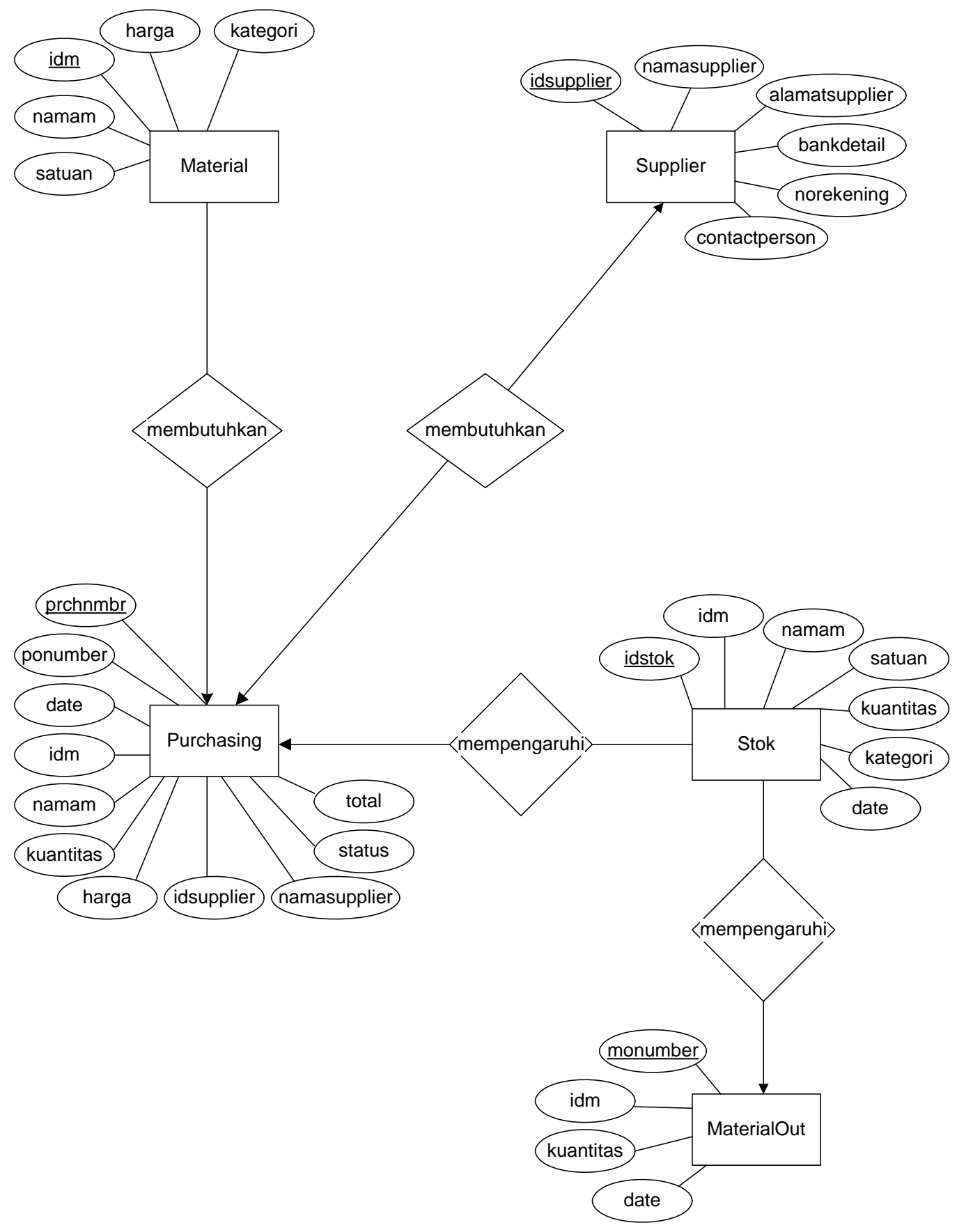

Gambar 4. Entity Relationship Diagram 


\section{HASIL TERCAPAI \& EVALUASI}

Main Form merupakan halaman utama dari aplikasi yang berisi Material In, Material Out, Availability Check, Purchasing, Material Master, Supplier Master, Item Pekerjaan dan Reporting Button. Form ini merupakan form utama sebelum User memilih untuk melakukan transaksi yang diinginkan. Berikut adalah contoh beberapa transaksi yang dapat dilakukan dengan menggunakan aplikasi ini,

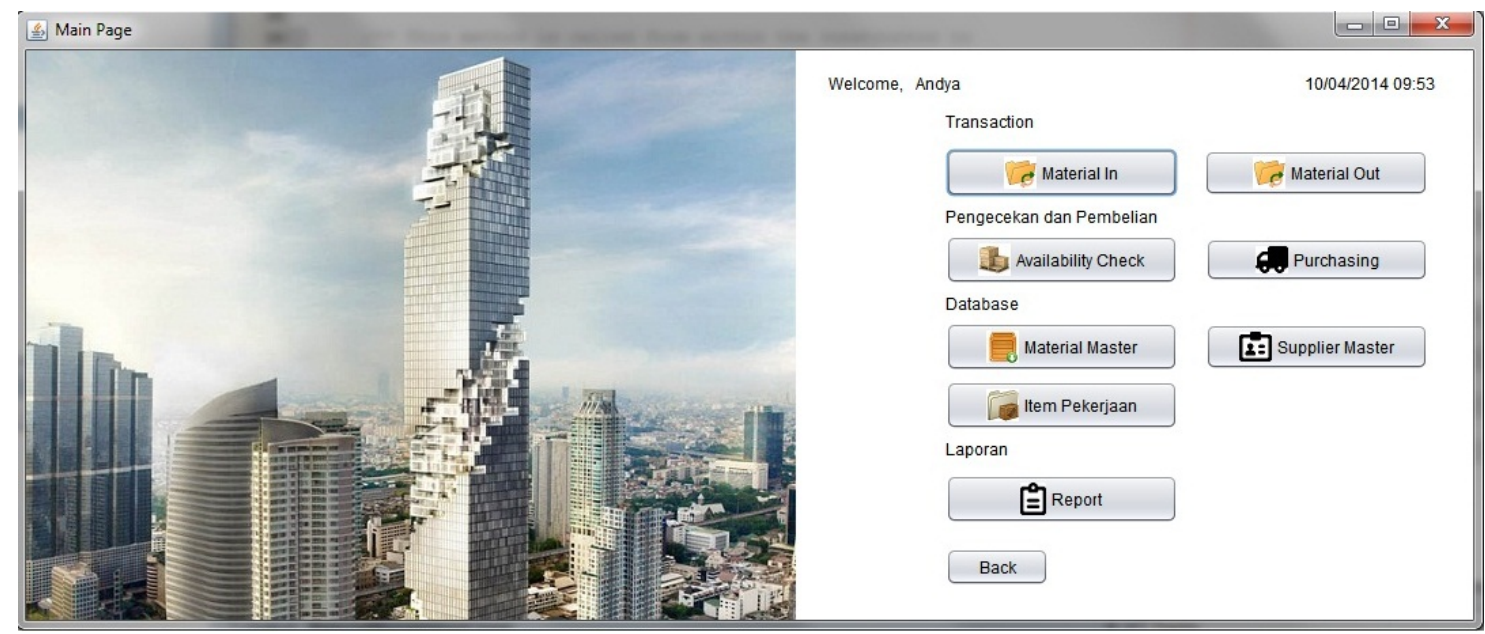

Gambar 5. Main Form.

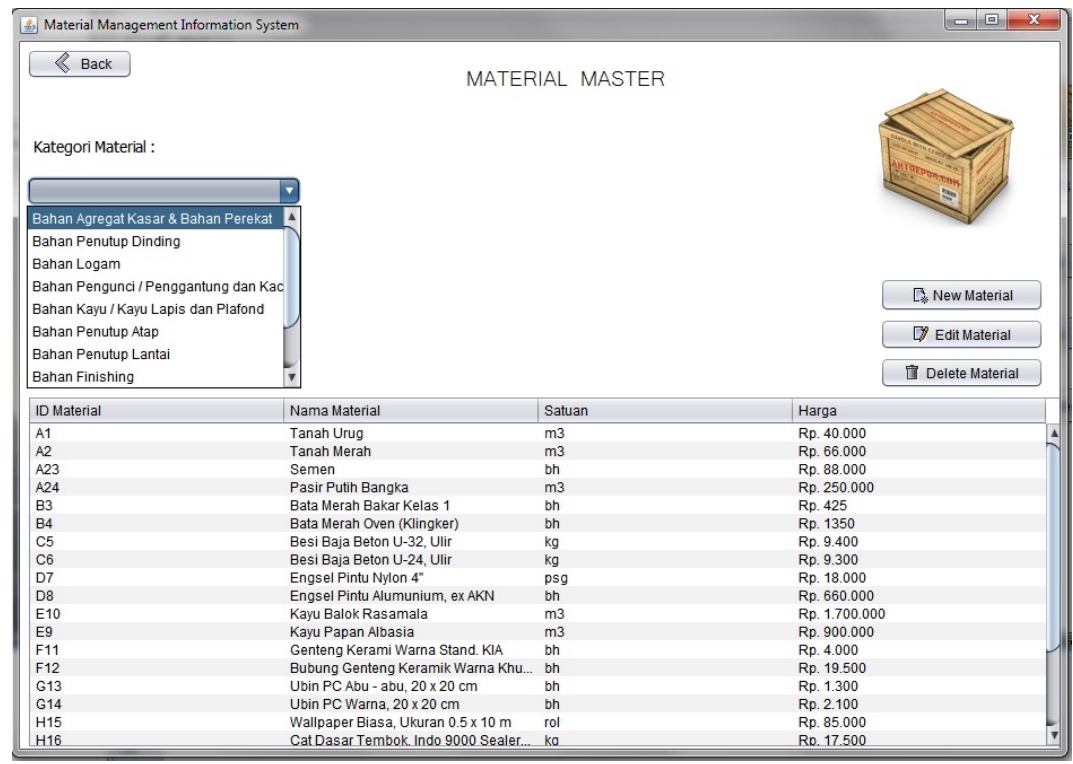

Gambar 6. Form Material Master. 
Form Material Master merupakan salah satu contoh tampilan aplikasi yang akan muncul setelah User memilih transaksi Material Master. Data material diambil dari database dan ditampilkan disini, kemudian dapat dilakukan pencarian material sesuai dengan kategorinya . Selain itu juga dapat dilakukan pembuatan data material baru, perubahan atau penghapusan data material.

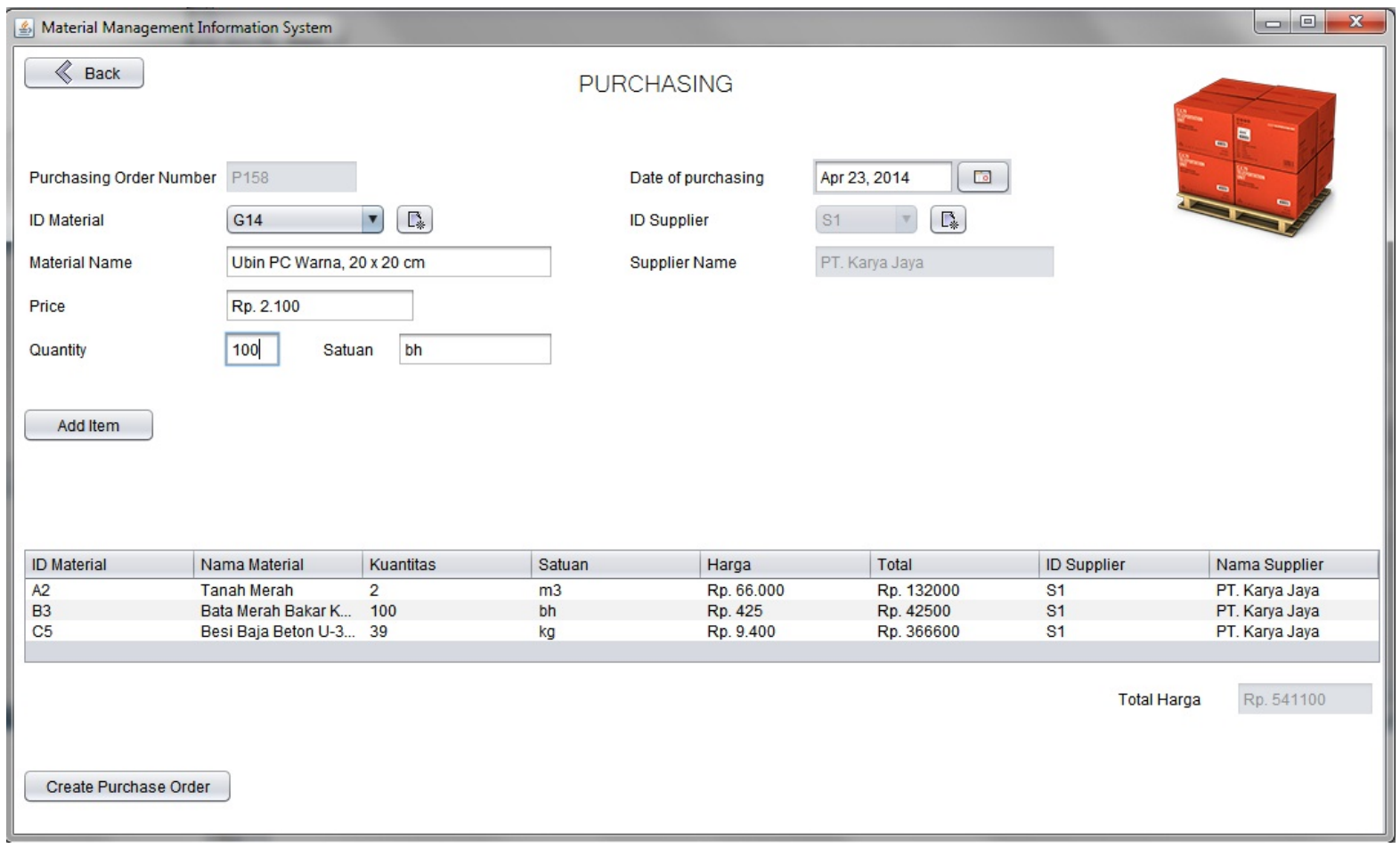

Gambar 7. Form Purchasing.

Form Purchasing merupakan salah satu contoh tampilan aplikasi yang akan muncul setelah User memilih transaksi Purchasing. Disini aplikasi mencatat semua data pembelian, baik dari data material yang dibeli, data supplier, tanggal pembelian dan secara otomatis dilakukan perhitungan harganya. User hanya tinggal memilih material yang ingin dibeli, jumlah pembelian, serta nama supplier. 


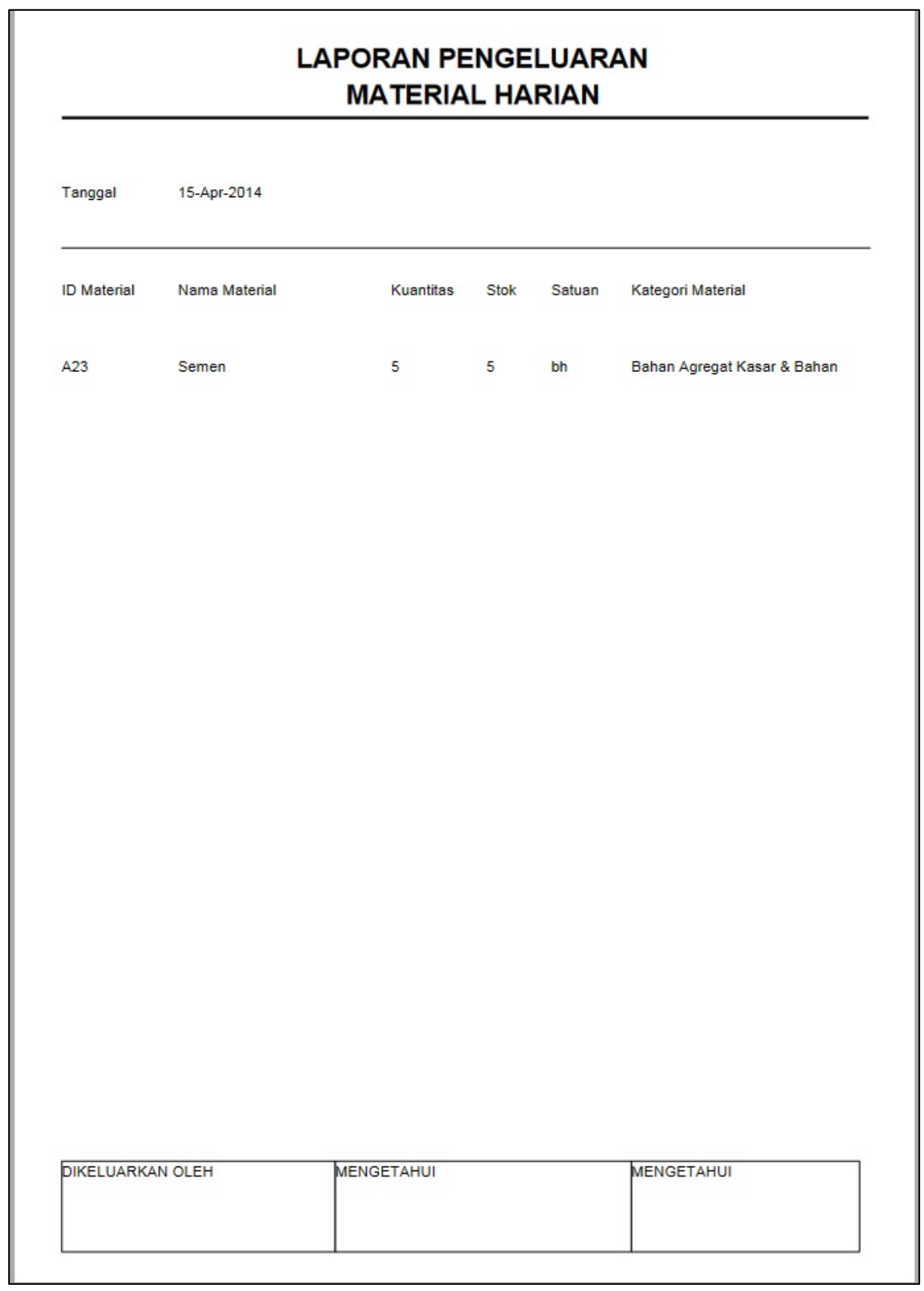

Gambar 8. Contoh Laporan dari Aplikasi. 
Aplikasi ini juga dapat mencetak laporan secara otomatis. Laporan terdiri dari berbagai macam sesuai dengan kebutuhan, seperti laporan pembelian material, laporan pengeluaran material harian atau laporan pengeluaran material mingguan

\section{KESIMPULAN}

Berdasarkan hasil penelitian dan pengujian dapat disimpulkan sebagai berikut:

1. Aplikasi Sistem Informasi Pencatatan Material untuk Pengadaan Barang Masuk dan Keluar bekerja dengan cara menyimpan dan mengolah data, sehingga mempercepat waktu pengerjaan data yang berlebihan dan tentunya lebih aman dan nyaman.

2. Aplikasi Sistem Informasi Pencatatan Material untuk Pengadaan Barang Masuk dan Keluar merupakan perbaikan dari sistem kerja manual yang berada di lapangan.

3. Keuntungan bagi perusahaan dengan adanya aplikasi ini memudahkan dalam memanajemen material untuk jangka waktu yang panjang.

4. Keuntungan aplikasi ini bagi pihak - pihak yang terlibat di lapangan yaitu memudahkan dalam memanajemen material yang ada di lapangan dan dapat digunakan untuk pembelajaran di masa yang akan datang.

\section{DAFTAR PUSTAKA}

1. Fakultas Teknik, Jurusan Teknik Sipil, 2000. "Petunjuk Pendidikan Sarjana Strata I Jurusan Teknik Sipil Universitas Kristen Maranatha Bandung”.

2. Universitas Kristen Maranatha. (2007), "Model Entity Relationship“, Universitas Kristen Maranatha.

3. Universitas Kristen Maranatha. (2006), "Pengantar Sistem Informasi“, Universitas Kristen Maranatha.

4. Tanubrata, Maksum. "Diktat Kuliah Rekayasa Pelaksanaan Konstruksi“, Universitas Kristen Maranatha Bandung.

5. Fathansyah. (2001). "Basis Data“, Penerbit Informatika Bandung.

6. Husen, A., “Manajemen Proyek“, Penerbit ANDI Yogyakarta.

7. Hakim S,R., Sutarto,. “Mastering Java“, Penerbit Elex Media Komputindo. 